\title{
Esthetic harmonization of front upper teeth using composite resin: a clinical case report
}

\author{
Harmonização estética de dentes ântero-superiores \\ com resina composta: relato de caso clínico
}

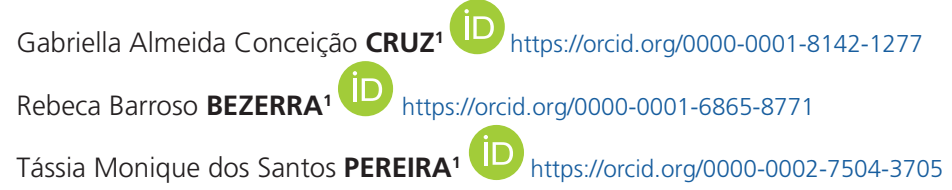

ABSTRACT

Every day, professionals who work with esthetics are faced with the challenge of meeting patients expectations who longs for a perfect smile, where every detail must show harmony and naturality. In this context, composite resin reanatomization is widely indicated for small corrections of color and shape in one or more dental elements, for diastema closure and sometimes for correction of small dental misalignment. The case report presented here discuss the planning and treatment for the esthetic and functional improvement of the dental units 1.1, 1.2, 2.1 and 2.2, by making direct restorations in composite resin. The patient sought the Faculty of Dentistry of UFBA in search of esthetic treatment, reporting dissatisfaction with the smile. During an evaluation, the thickness and size of the upper back teeth were dissonant, besides of the interincisal diastema and a discrete gyroversion of the lateral incisors, which together compromised the esthetic area of the smile. Therefore, the proposed treatment for solving this clinical situation was direct esthetic rehabilitation with composite resin in units 1.2 to 2.2. After obtaining the study models, it was accomplished diagnostic waxing and silicone guide as auxiliary resources on the planning and restorative stage. Nanoparticulate composite resins were used, making a stratification technique to obtain a harmonic result. The treatment was able to reproduce the esthetic and natural appearance of the teeth, through a conservative alternative, fast and with an excellent cost-benefit relation when compared to the indirect techniques.

Indexing terms: Dental esthetics. Diastema. Smiling.

\section{RESUMO}

Profissionais que trabalham com estética se deparam diariamente com o desafio de atender as expectativas dos pacientes que anseiam por um sorriso perfeito, onde cada detalhe deve evidenciar harmonia e naturalidade. Neste contexto, a reanatomização em resina composta é amplamente indicada, para pequenas correções de cor e forma, em um ou mais elementos dentais, para fechamento de diastemas e, por vezes, para correção de pequenos desalinhamentos dentais. O relato de caso aqui apresentado discute o planejamento e tratamento realizado para a melhora estética e funcional das unidades dentais 1.1, 1.2, 2.1 e 2.2, por meio da confecção de restaurações diretas em resina composta. A paciente procurou a Faculdade de Odontologia da UFBA em busca de tratamento estético, relatando insatisfação com o sorriso. Durante a avaliação, foi observada desarmonia de espessura e tamanho em dentes ântero-superiores, além de diastema interincisal e discreta giroversão dos incisivos laterais, que em conjunto

$\nabla \nabla \nabla v$

1 Universidade Federal da Bahia, Faculdade de Odontologia, Departamento de Clínica Odontológica. Av. Araújo Pinho, 6, 40110-040, Canela, Salvador, BA, Brasil. Correspondence to: TMS PEREIRA. E-mail: <tassia_moniq@hotmail.com>.

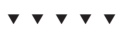

Cruz GAC, Bezerra RB, Pereira TMS. Esthetic harmonization in anterior teeth. RGO, Rev Gaúch Odontol. 2021;69:e2021011. http://dx.doi. org/10.1590/1981-86372021001120190093 
comprometia a zona estética do sorriso. O tratamento proposto para solucionar esta situação clínica foi a reabilitação estética direta com resina composta nas unidades 1.2 ao 2.2. Após a obtenção dos modelos de estudo, foi realizado o enceramento diagnóstico e guia de silicona como recursos auxiliares no planejamento e etapa restauradora. Foram utilizadas resinas compostas nanoparticuladas, realizando a técnica de estratificação para a obtenção de um resultado harmônico. O tratamento realizado conseguiu reproduzir a aparência estética e natural dos dentes, através de uma alternativa conservadora, rápida e com ótima relação custo-benefício quando comparada às técnicas indiretas.

Termos de indexação: Estética dentária. Diastema. Sorriso.

\section{INTRODUCTION}

Professionals who work with aesthetics face the challenge of meeting the expectations of their patients on a daily basis. In dentistry, the smile is considered a fundamental part of personal presentation and one of the most valued aspects of the aesthetic framework of the face. The search for a perfect smile becomes one of the biggest challenges faced by operators, where every detail must show harmony, naturalness and expressiveness [1-2].

This sense of oral aesthetics is related to the promotion of self-esteem, since the smile is an important element in the harmonic dento-facial composition, and many times any changes in appearance, such as diastemas and giro-version can cause social implications [2]. However, it is up to the dental-surgeon to analyze dental aesthetics, from the broadest segments, such as facial composition, to the most specific, such as dental morphology features, seeking harmony between what the patient wants, the adequate planning and scientific knowledge [3].

Nowadays, Dentistry has several restorative options: direct and indirect procedures with composite resins or ceramics. Nonetheless, for any type of procedure, the professional must choose the least invasive treatment, with greater preservation of the dental structure [4]. Therefore, the most appropriate treatment of the imperfections on the aesthetic plane depends on the integration of the knowledge related to aesthetics, restorative materials and techniques available today [5].

Due to the polychromatism of natural teeth in aesthetic restorations it is extremely important to use a material that has a wide variety of colors, with fluorescence and opalescence properties that allows to work with the opacity and translucency characteristics present to a greater or lesser degree in different areas of the natural teeth [5-9].

The appearence and enhancement of adhesive systems, together with the improvement of composite resins, made possible to perform minimally invasive restorative treatments on anterior teeth in the most diverse clinical indications with safety and efficiency [5-6]. The development of the new composite resins has provided an improvement of the mechanical properties, increasing the resistance to abrasion and compression of these materials, as well as a low polymerization shrinkage and varied colour options, presenting itself as one of the most accessible materials [7-9].

Among the main advantages of this material, the following stand out: good surface smoothness, easy polishing, radiopacity [10-11], coefficient of linear thermal expansion similar to that of the tooth structure, resistance to compression, low cost, durability of the restoration, speediness of reaching results for reversibility of the procedure [12], using a minimally invasive technique [11-14].

Another advantage of the direct process is the cost of the procedure, which is relatively lower when compared to those involving laboratory parts. The number of sessions to run also proves to be an important advantage, although this is relatively long. The resistance and colour stability of composite resins, even though inferior compared to the ceramics are satisfactory and are conditioned to the indications of the case and conditions of execution and preservation $[5,15]$.

The reanatomization with composite resins is indicated for small colour and shape corrections, in one or more dental elements. An example is its indications for closing diastemas and simpler cases for correcting minor dental misalignments. When properly indicated and carried out, this treatment has high durability, even with the possible subsequent colour changes due to the food rich in dyestuffs $[10,15]$.

Based on the above considerations, the objective of the present work is to present and discuss the treatment planned and carried out for the aesthetic and functional improvement of units 11, 12, 21 and 22, by making direct composite resin restorations. 
The case report corroborates resolution 466/2012 of the National Health Council / Ministry of Health of Brazil and was submitted and approved by the Ethics Committee of the UFBA Dentistry School, opinion number 2.109.545.

\section{CASE REPORT}

A 24-year-old female patient attended the Dentistry II outpatient clinic at the Federal University of Bahia, reporting dissatisfaction with the appearance of her antero-superior teeth. On clinical examination, deficient composite resin restorations were observed in the mesial region and with the incisal edge of the upper central incisors, with a small diastema and unfavorable proportions, in which unit 11 had a smaller width than unit 12 (figures 1 and 2). The lateral incisors showed subtle gyroversion (figures 1 and 2). After the clinical evaluation for better planning of the case, extra and intraoral photographs were taken and the study model was made. The treatment plans were presented and in agreement with the patient, it was decided to re-anatomize the lateral incisors and close the diastema between the central incisors, as well as lengthen them using the direct technique with composite resin.

To obtain the study model, the arches were moulded with Hidrogum alginate 5 (Zhermack Labordental, Brazil) and casting special stone plaster Durone type IV (Dentsply, Petrópolis, RJ, Brazil). Following, diagnostic waxing was performed in order to establish an adequate anatomy and height / width ratio. This waxing was performed according to the protocol proposed by Machado [16]. Subsequently, the silicone guide was made to guide the application of the composite resin incrementally. In this way, the diagnostic waxing was moulded with the Zetalabor condensing silicone (Zhermack, Badia Polesine, RO, Italy), following all the manufacturer's guidelines regarding its handling. After the setting time, the excesses of the silicone matrix

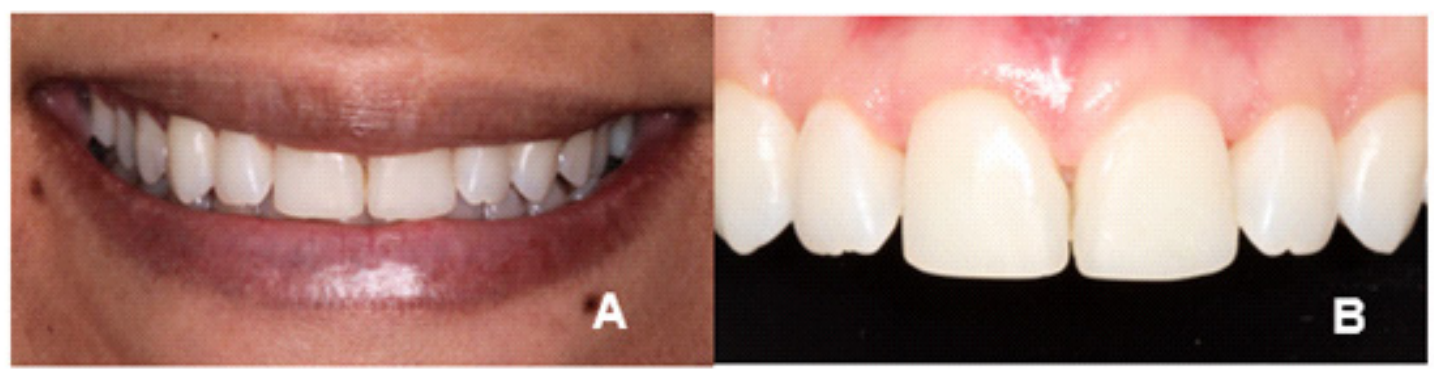

Figure 1. A) Initial clinical aspect of the smile; B) Approximate picture of the anterior aesthetic zone.

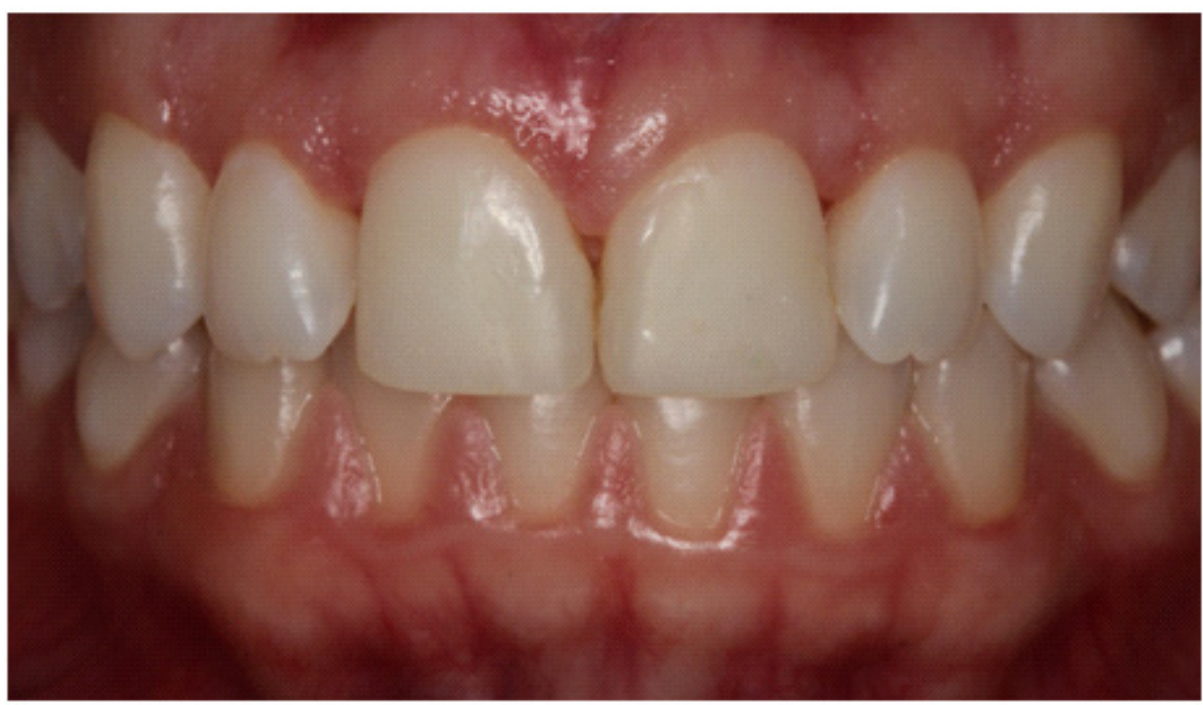

Figure 2. Initial intraoral picture. 
(palatal guide) were removed with the aid of scalpel blade \#15 (Solidor, Barueri, SP, Brazil) obeying the contours of the incisal edges (figure 3).

Prior to colour selection, dental prophylaxis was performed with extra-fine pumice stone SS White (S.S. White, Brazil) and water. Under natural light, small increments of the composite resins to be used were deposited on the surface of the dental units in question without the acid conditioning and prior adhesive system, then they were photoactivated with the light curing Optilight Max (Gnatus, Ribeirão Preto, SP, Brazil). After selection, the operative field was isolated with the aid of

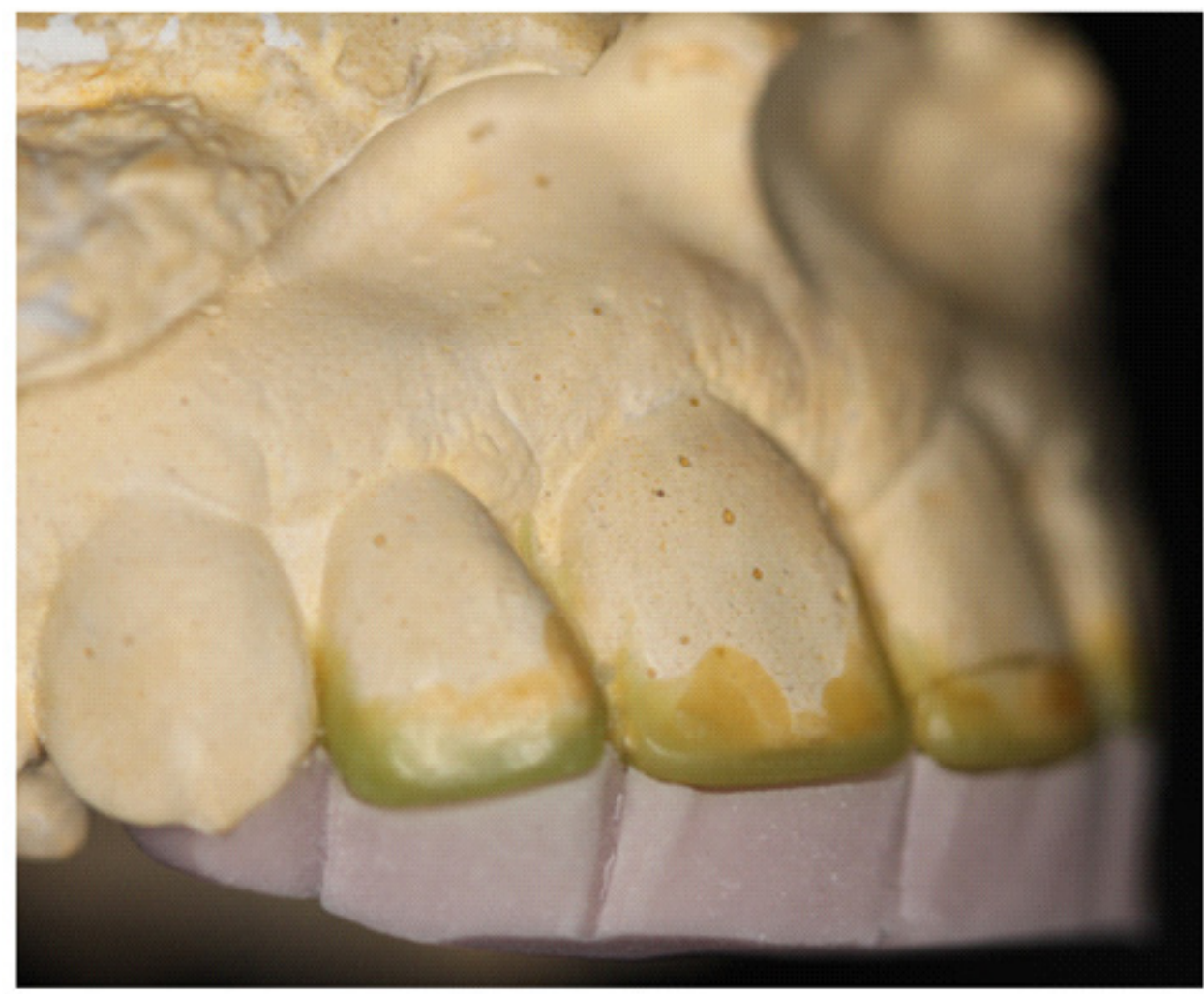

Figure 3. Silicone guide made from diagnostic waxing.

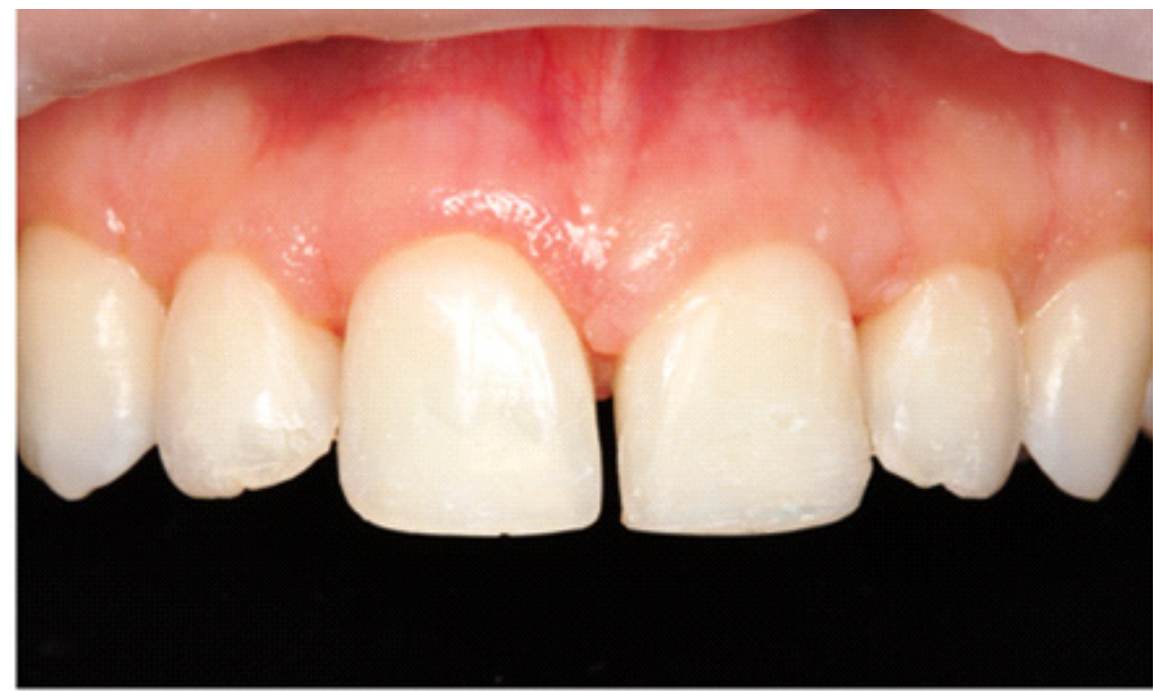

Figure 4. Clinical aspect after removal of defective restorations and abrasion of the vestibular surface. 
the Optragate lip and cheek retractor (Ivoclar Vivadent, Liechtenstein). Then, the restorations in units 11 and 21 were removed and in elements 12 and 22 an ameloplasty was performed, with the $3195 \mathrm{~F}$ diamond tip (KG Sorensen, Cotia, SP, Brazil) and with Sof-Lex Pop-On discs (3M ESPE, Sumaré, SP, Brazil). After these wears, an abrasion was performed on the faces to be conditioned, with Sof-Lex Pop-On discs (3M ESPE, Sumaré, SP, Brazil) (figure 4).

Next, selective enamel etching was carried out on units 12 to 22 on the faces that will receive the composite resin, with 35\% phosphoric acid Adper Scotchbond (3M ESPE, Sumaré, SP, Brazil) for 30 seconds. After acid removal, abundant washing and drying with sterile absorbent paper, the Single Bond Universal adhesive system (3M ESPE, Sumaré, SP, Brazil) was actively applied with the aid of the disposable applicator (microbrush, Kgbrush) throughout the enamel's region, and for units 12 and 22, in small dentin exposure areas. After waiting for 20 seconds, each face was photoactivated for 10 seconds with the Optilight Max device (Gnatus, Brazil).

With the substrates properly prepared, the restorative treatment was started with the reanatomization of the lateral incisors (figure $5 \mathrm{~A}$ and $5 \mathrm{~B}$ ) followed by the central incisors (Figure $5 C$ ), choosing this sequence due to the gyroversion of the lateral incisors. For both stages, the same method of inserting increments was performed using the stratified technique, described below: A thin layer of Filtek Z350 XT nanoparticulate composite resin (3M ESPE, Sumaré, SP, Brazil) was inserted in the WE color, in silicone guide, taking position in the arch and light-curing for 20 seconds, to mimic the palatal enamel.

Afterwards, the dentin part was rebuilt in A1D color, taking care not to fully extend the composite resin to the proximal and contour of the incisal edge, leaving this space to be filled by an enamel resin, after photoactivation by 20 seconds, a new layer of increments in the color A1E was used to mimic the vestibular enamel, followed by photoactivation for 20 seconds, finally, another layer of the Filtek Z350 XT nanoparticulate composite resin (3M ESPE, Sumaré, SP, Brazil) at WE color was positioned on the incisal edges and photoactivated for 20 seconds.

The composite resins used were inserted incrementally with the aid of the Safident-Almore spatulas (Cosmedent, Curitiba, PR, Brazil) and IPC-Long (Cosmedent, Curitiba, PR, Brazil) and brushes \# 2 and \# 3 (Cosmedent, Curitiba, PR, Brazil).

The reanatomization were completed with central incisors bearing $11 \mathrm{~mm}$ in height and a $2 \mathrm{~mm}$ step with the lateral incisors. Then, excesses and initial finishing were carried out with diamond tips 3118F (KG Sorensen, Cotia, SP, Brazil) on the palatal faces, 3195F (KG Sorensen, Cotia, $\mathrm{SP}, \mathrm{Brazil})$ in the proximal and incisal region and $1190 \mathrm{~F}$ (KG Sorensen, Cotia, SP, Brazil) in the cervicals (Figure 5D). In addition, scalpel blades \#15 (Solidor, Barueri, São Paulo, Brazil), Interproximal Flexistrip abrasive (Cosmedent, Chicago, United States) and Sof-Lex Pop-On discs (3M ESPE, Sumaré, SP, Brazil) were used fine and medium grain.
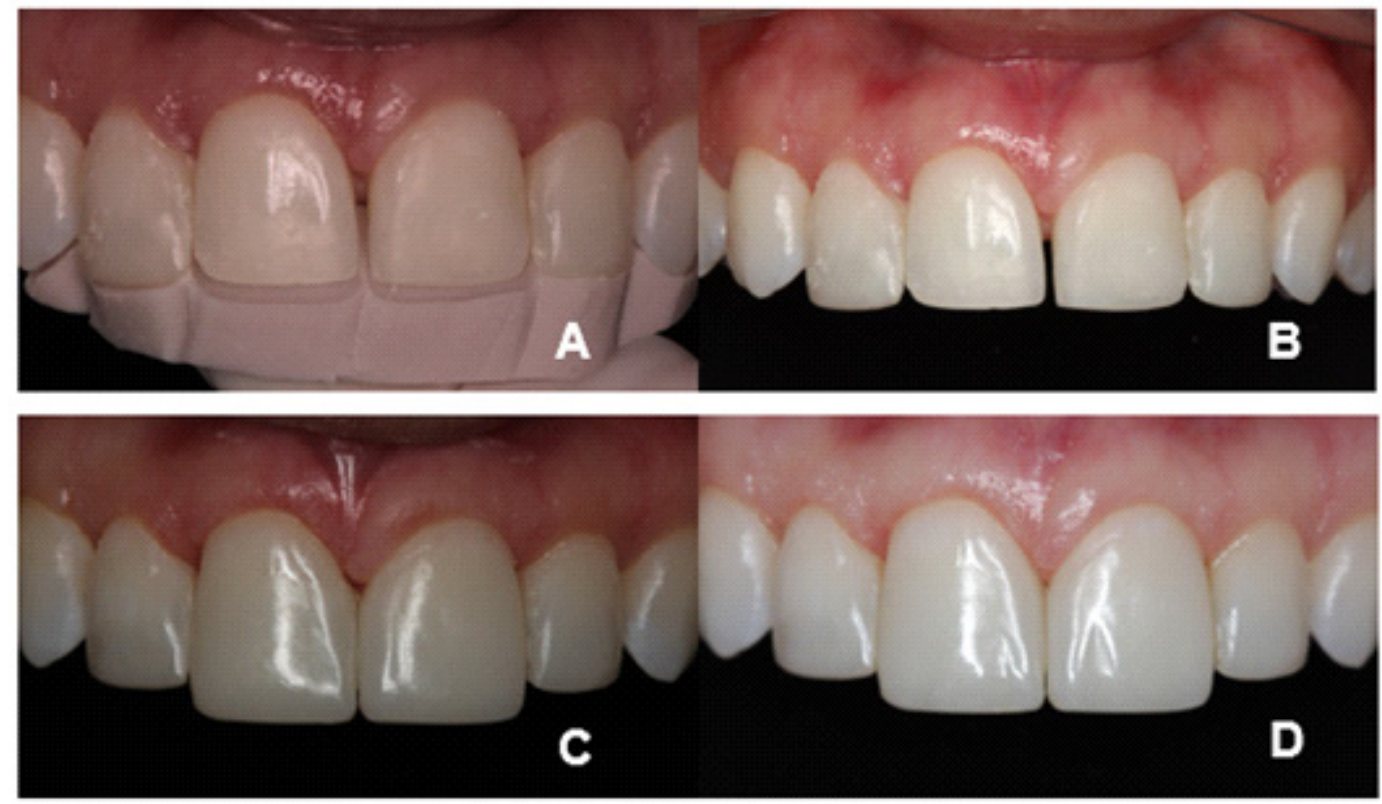

Figure 5. A) Orientation by the Silicone Guide; B) Reanatomization of the lateral incisors; C) Reanatomization of central incisors; D) Initial finish. 
In the following session, the texturisation of the restored units was performed (figures $6 \mathrm{~A}$ and $6 \mathrm{~B}$ ), with 32-blade multilaminated drills (KG Sorensen, Cotia, SP, Brazil). Later, maximal habitual intercuspation $(\mathrm{MIH})$, protrusion and laterality were evaluated in order to eliminate interference and premature contacts. The excess areas were marked with Accufilm 2 carbon paper (Parkell, USA) and adjusted with a diamond tip \# 3118 F (KG Sorensen, Cotia, SP, Brazil). For the final finishing and polishing, siliconized tips (Cosmedent, Chicago, United States) and Sof-Lex Pop-on aluminum oxide discs (3M ESPE, Sumaré, SP, Brazil) were used, following the decreasing order of granulation, followed by use of silicon carbide brush and finally felt discs (Cosmedent, Chicago, United States) with diamond paste Enamelize (Cosmedent, Chicago, United States).

At the end of the proposed treatment, comparing the initial situation of the case, it is possible to observe the clinical evolution and aesthetic improvement achieved (figures 7A and 7B). The end result was a natural, balanced smile, with reproduction of details that provided aesthetic harmony (Figure 8) and the patient's satisfaction with her smile.

\section{DISCUSSION}

The unsatisfactory anatomical shape of the anterosuperior teeth [17], gyro-versions, diastemas, old restorations and colour changes, even if in most cases they do not damage the masticatory function and the biology of the tissues are among others, the causes of aesthetic nonconformity that direct patients to seek aesthetic restorative methods $[17,18]$.

The significant evolution of dental materials and restorative techniques that provide increasingly conservative, aesthetic and functional procedures has made the philosophy of minimal dental intervention possible [4]. Improvements in the direct use adhesive restorative system make it a great option, considering that dentists can perform restorations with or without minimal wear, preserving the tooth structure and reproducing the desired contour [19].

The technique of direct adhesive reanatomization is one of the options in cases of dental disharmonies,

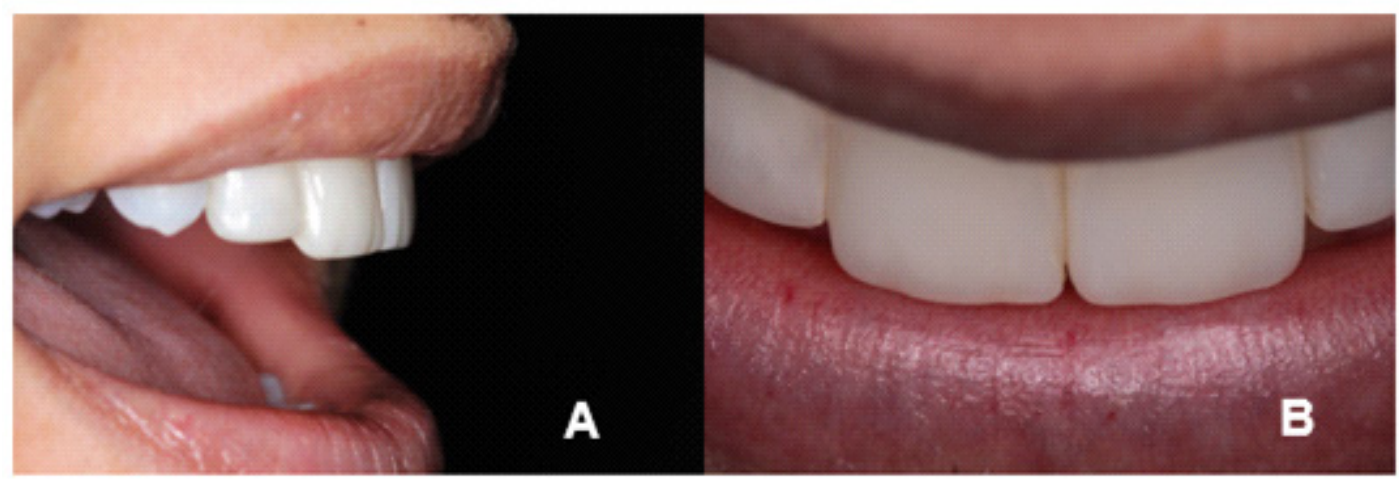

Figure 6. Texturisation of the restorations in order to reproduce details similar to those of natural teeth, in direct side view; B) Aspect of the translucency of the incisal edge.

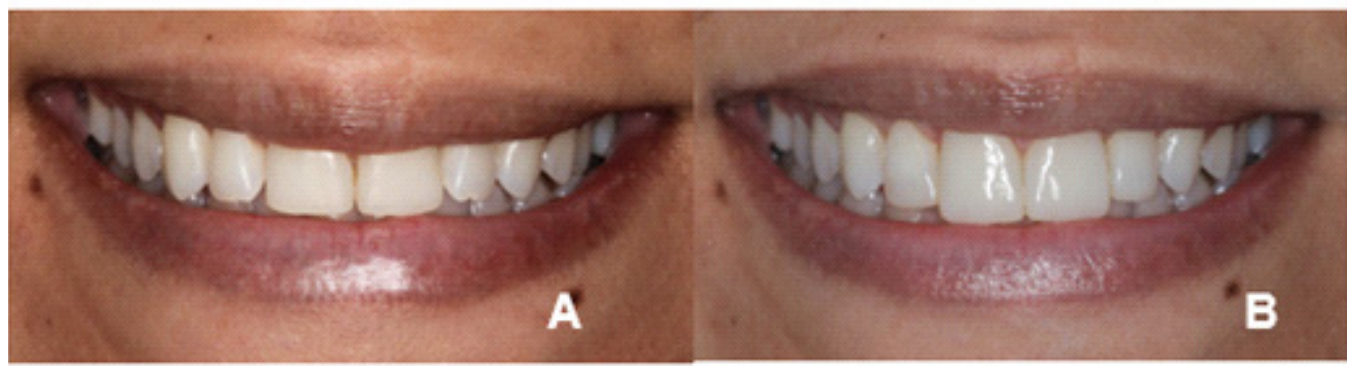

Figure 7. Clinical evolution: A) Initial aspecto $f$ the smile; B) Final aspect of the smile with a convex incisal line around the lower lip. 

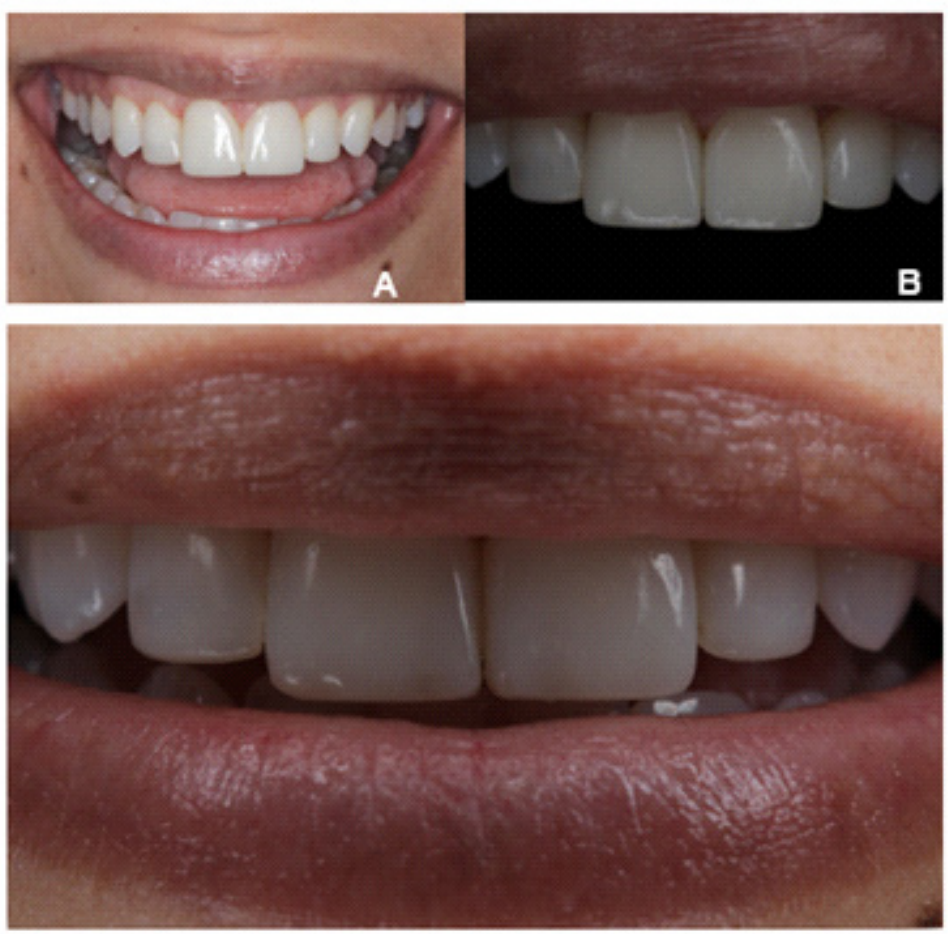

Figure 8. Final clinical aspecto $f$ the smile; B) Approximate picture of the anterior aesthetic zone; C) Exposure of the upper central incisors.

since current resins exhibit a wide variety of colors and effects, facilitating different combinations of translucency and opacity [14]. In these types of treatments, the dental surgeon refines his artistic sense in order to reproduce the nuances and dental polychromatism.

However, this technique has some negative points such as sensitivity to operative contamination, polymerization contraction, need for operator skill and longer clinical time. Therefore, it must be carefully performed to avoid marginal infiltration at the toothrestoration interface [20].

In the present clinical case, the treatment was planned according to the revised literature, with the objective of rehabilitating the anterior units affected by dental disharmony [2] by means of direct adhesive restorations with the help of a silicone guide for the reanatomization of anterosuperior incisors.

The composite resins are widely used in dental treatments, in addition to attracting the attention of researchers, who constantly seek changes in their composition, being classified according to the size and quantity of inorganic particles [20].

In addition, it is recommended the use of diagnostic waxing, associated with the use of the silicone matrix [21], which helped the proper planning and three-dimensional demonstration of the case to the patient. The technique of the silicone guide obtained from the diagnostic waxing, favors the making of the palatal face in addition to establishing the width and height of the incisal edges, helping in the restorative process [11].

The innovation of nanoparticulate resins is in the individual silanization of the charge particles forming the socalled "nano-agglomerates" [17], in other words, masses of homogeneous particles that prevent their release or straying as they can happen with microhybrids. In addition to presenting high surface smoothness, brightness and colour stability, high resistance to compression, fracture and wear and, also, for presenting high polishing durability, due to its different abrasion pattern during wear. In other words, the nanoparticle resin combines the advantage of the microparticle resin, superficial smoothness, and, also hybrid's resin, fracture's resistance, making this composite resin an excellent option for anterior teeth $[17,20]$. Such characteristics justify the choice for this type of resin for the execution of this clinical case.

A systematic review determined based on in vitro studies that when using universal adhesives, it recommended the previous conditioning with phosphoric 
acid of the dental enamel, seeking to boost the resistance to micro-shear and microtensile [22]. Thus, in the present case, selective enamel etching was carried out for 30 seconds before the application of the universal adhesive system over the entire surface to be restored, seeking to optimize the adhesion process.

The stratified technique of inserting the composite resin helps to mimic the nuances of the natural tooth, where small increments of composite resin for the dentin colour, with a characteristic of greater opacity and opalescence are applied until a thickness corresponding to that found in natural teeth, as well as the resin related to the enamel, which will be the last layer $[17,21]$. In the presented case, the choice for the stratification technique was motivated by the aesthetic-functional situation of the area to be reanatomized as the dental elements have polychromy and varying degrees of translucency in different areas of the same dental element. Such needs were addressed, since stratification interfered with the reflection of light and provided a satisfactory aesthetic result for the patient and the professional.

A survey to evaluate the influence of different distances to the light source, as well as the exposure time recommended by the respective manufacturer and twice that recommended; in the photopolymerization capacity of 4 different types of composite resins in increments of $2 \mathrm{~mm}$ thick, they found that microhardness was influenced by the distance from the light source and the type of composite resin [23]. Regarding the time of exposure to light, there were no significant diferences [23]. For the authors [23], the direct incidence of the light source on the surface of the resin increments during the time recommended by the manufacturer allows a correct polymerization. Thus, combining the advantages obtained with the stratified composite resin technique with the need for an efficient polymerization of the resin component aiming to achieve better mechanical and aesthetic results in the long term, each increment of composite resin was photoactivated, maintaining the emission point of light close to the surface, following the manufacturer's recommendations for photoactivation time.

In order to restore and reconstitute the anterior teeth, countless details must be evaluated, seeking a better dento-facial harmonization. A reference proportion for the anterior aesthetic balance is, for example, that the central incisors have crowns from 9.5 to $11 \mathrm{~mm}$ high, whose incisal edge is below the canine cusp tip, as well as the step between central and lateral incisors. Ranging from 1.0 to $1.5 \mathrm{~mm}$, for women [16]. In our study, the height established for the central incisors was $11 \mathrm{~mm}$ with a $2 \mathrm{~mm}$ step for the lateral incisors, values close to those already mentioned in the literature which met the patient's personal aesthetic desires.

When assessing the effects of eight finishing and polishing techniques on the surface roughness and color stability of five types of composite resin, Gönülol and YIImaz [24], found that the final finish using the complete sequence of Sof-Lex discs was satisfactory in all tested composite resin groups, as well as, a statistically significant correlation between the values of surface roughness and colour variation [24]. Considering the information above, aiming at a lower surface roughness and less colour variation of composite resin restorations, the final finishing and polishing was performed using siliconized tips (Cosmedent, Chicago, United States) and Sof-Lex Popon aluminium oxide discs (3M ESPE, Sumaré, SP, Brazil), according to the decreasing order of granulation, followed by the use of silicon carbide brush and finally felt discs (Cosmedent, Chicago, United States) with diamond paste Enamelize (Cosmedent, Chicago, United States).

\section{CONCLUSION}

The direct adhesive restorative technique proved to be an excellent option for aesthetic restorative treatment, due to the possibility of mimicking dental structures and consequently restoring the harmony of the smile naturally. However, an adequate aesthetic and functional planning is necessary, as well as the mastery of the technique and deep knowledge of the restorative materials to be used, aiming at obtaining favorable results, thus reestablishing the self-esteem and satisfaction of both the patient and the professional.

\section{Collaborators}

GAC CRUZ, writing of the manuscript. RB BEZERRA, responsible for the clinical conduct and final analysis of the manuscript. TMS PEREIRA, critical review of the text.

\section{REFERENCES}

1. Schwarz V, Simon LS, da Silva SA, Ghiggi PC, Cericato GO. Fechamento de diastema com resina composta: relato de caso. 
J Oral Invest. 2013;2(1):26-31. http://dx.doi.org/10.18256/2238510X/j.oralinvestigations.v2n1 p26-31

2. Santos BC, Dantas LF, Silva SC, Lima LHA, Agra DM, Fernandes DC. Odontologia estética e qualidade de vida: revisão de literatura. Ciênc Biol Saúde. 2016;3(3):91-100.

3. Rodrigue SR, Argolo S, Calvacanti AN. Reanatomização Dental com Resina Composta. Rev Bahiana Odontol. 2014;5(3):182-192.

4. Higashi C, Gomes JC, Kina S, de Andrade OS, Hirata R. Planejamento estético em dentes anteriores. In: Miyashita E, de Mello AT. Odontologia Estética- Planejamento e técnica. Porto Alegre: Artes Médicas; 2006.p. 139-154.

5. Hirata R, Ampessan RL, Liu J. Reconstrução de dentes anteriores com resinas compostas - Uma Seqüência de Escolha e Aplicação de Resinas. JBC. 2001;5(25):16-25.

6. Kina $M$, Leal FA, Fabre AF, Martin OCL, Coimbra MC, Kina J. Tratamento restaurador estético minimamente invasivo através da técnica direta com compósito. Relato de caso clínico. Arch Health Invest. 2015;4(4):50-55.

7. Bispo LB. Resina composta nanoparticulada: Há superioridade no seu emprego? Rev Dentística on line. 2010;19:21-24.

8. Da Silva JMF, Rocha DM, Kimpara ET, Uemura ES. Resinas compostas: estágio atual e perspectivas. Rev Odonto. 2008;16(32):98-104. http://dx.doi.org/10.15603/2176-1000/ odonto.v16n32p98-104

9. Fernandes HGK, Silva R, Marinho MAS, Oliveira POS, Silva R, Ribeiro JCR, et al. Evolução da resina composta: Revisão da Literatura. Rev Universidade Vale do Rio Verde. 2014;12(2):401-411. http://dx.doi.org/10.5892/ruvrd.v12i2.1465

10. Abreu R, Schneider M, Arossi GA. Reconstrução anterior em resina composta associada a pino de fibra de vidro: relato de caso. Rev. Bras. Odontol. 2013; 70(2):156-159.

11. Braga AT, Monteiro DDH, Munari LS, Cornacchia TPM. Acompanhamento de restaurações em diastemas anteriores com resina composta pela técnica da barreira palatina: Relato de caso. Rev Odontol Bras Central. 2016;25(74):112-17.

12. Coelho LGC, Machado WC, Soares MRPS, Melo KA. Reanatomização estética em paciente com hipodontia, dente conoide e permanência de elemento decíduo. RPG. 2010;17(4):204-208.

13. Araújo EP, Rocha Filho LA, Brum GT, Caldo-Teixeira AS. Fechamento de diastemas com restaurações diretas de resina composta - Relato de caso. Rev Saúde. 2009;1(3):33-38.

14. Lima WBR, Leite JT, França RM, Brito MCT, Uchoa RC, Andrade AKMB. Reabilitação estética anterior pela técnica do facetamento:
Relato de Caso. Rev Bras Ciênc Saúde. 2013;17(4):363-370. http://dx.doi.org/10.4034/RBCS.2013.17.04.07

15. Campos PRB, Amaral D, Chaves da Silva MA, Barreto SC, Pereira GDS, Prado M. Reabilitação da estética na recuperação da harmonia do sorriso: relato de caso. RFO UPF. 2015;20(2):227-231.

16. Machado AW. 10 commandments of smile esthetics. Dental Press J Orthod. 2014;19(4):136-57.

17. Azevedo N, Galvão G, Nihi VSC, Hoeppner MG, Nihi FM. Otimização do sorriso com restaurações diretas de compósito resinoso nanoparticulado. Cient Ciênc Biol Saúde 2015;17(1):43-9. http://dx.doi.org/10.17921/24478938.2015v17n1p42-48

18. Reis GR, Vilela ALR, Silva FP, Borges MG, Santos-Filho PC, Menezes MS. Minimally invasive approach in esthetic dentistry: composite resin versus ceramics veneers. Biosci J. 2017;33(1):238-46 http:// dx.doi.org/10.14393/BJ-v33n1a2017-34617

19. Chaves LP, Schmitt VL, Consolgmano E, Frenken RP, Mondelli RFL, Wang L. Resin composite build-ups for complementig multidisciplinar esthetic na funcional dental treatments: a case report. Braz Dent Sci. 2015;18(1):28-33. http://dx.doi. org/10.14295/bds.2015.v18i1.1069

20. Stefani A, Fronza BM, Andre CB, Giannini M. Abordagem multidisciplinar no tratamento estético odontológico. Rev Assoc Pau Cir Dent. 2015;69(1):43-7.

21. Meirelles L, Bavia PF, Vilanova LSR. Aplicações clínicas do enceramento diagnóstico na reabilitação oral- uma revisão de literatura. Rev Fac Odontol Lins. 2013;23(1):20-25. http:// dx.doi.org/10.15600/2238-1236/fol.v23n1p20-25

22. Rosa, WLO; Piva, E; Silva, AF. Bond strength of universal adhesives: A systematic review and meta-analysis. J Dent. 2015;43:765-76. $<$ https://doi.org/10.1016/j.jdent.2015.04.003>

23. Borges A, Pitta-Lopes J, Portugal, J. Influência do tempo de exposição e distância à luz na capacidade de fotopolimerização de compósitos. Rev Port Estomatol Med Dent Cir Maxilofac. 2015;56(3): 166-72. http://dx.doi.org/10.1016/j. rpemd.2014.11.141

24. Gönülol, N; Yilmaz, F. The effects of finishing and polishing techniques on surface roughness and color stability of nanocomposites. J Dent. 2012;40:64-70. http://dx.doi. org/10.1016/ j.jdent.2012.07.005

Received on: 5/6/2019 Final version resubmitted on: 2/10/2019 Approved on: 22/11/2019 